\title{
Biocontrol of Foot and Root Rot Disease of Grasspea (Lathyrus sativus) by Dual Inoculation with Rhizobium and Arbuscular Mycorrhiza
}

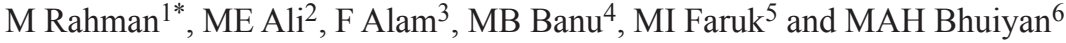 \\ ${ }^{1 \& 4}$ Scientific Officer, Soil Microbiology Laboratory, Bangladesh Agricultural Research Institute, Gazipur-1701, Bangladesh; ${ }^{2 \& 3}$ Senior Scientific Officer, Soil \\ Microbiology Laboratory, Bangladesh Agricultural Research Institute, Gazipur-1701, Bangladesh; ${ }^{5}$ Senior Scientific Officer, Plant Pathology Division, \\ Bangladesh Agricultural Research Institute, Gazipur-1701, Bangladesh; ${ }^{6}$ Principal Scientific Officer, Soil Microbiology Laboratory, Bangladesh Agricultural \\ Research Institute, Gazipur-1701, Bangladesh
}

\begin{abstract}
The present study was carried out to evaluate the effect of indigenous arbuscular mycorrhizal fungi (AMF) and Rhizobium (R) on plant growth and their biocontrol against grasspea foot and root rot disease caused by Sclerotium rolfsii. The bio-control potential of these bio-agents against foot and root rot pathogen was carried out under pot culture condition using AMF alone or in combination with rhizobial inoculum in the nethouse of Soil Science Division, Bangladesh Agricultural Research Institute, Joydebpur, Gazipur during 2014-2015 through 2015-2016. The experiment was designed in RCBD with 8 treatments and 4 replications. Grasspea variety BARI Khesari-1 was used as a test crop. Peat based rhizobial inoculum (BARI RLs-10) was used in this experiment @ $50 \mathrm{~g} \mathrm{~kg}^{-1} \mathrm{seed}_{\text {. The }}$ AM fungi used in this experiment were Glomus fusianum, Glomus macrocarpum, Glomus warcuppi, Acaulospora foveata, Acaulospora denticulate, Gigaspora albida, Gigaspora rosea, Glomus spp. etc. Soil based AM inoculum containing about approximate 252 spores and infected root pieces of the host plant was used pot ${ }^{-1}$. There were eight treatments viz. $\mathrm{T}_{1}$ : Arbuscular mycorrhiza (AM), $\mathrm{T}_{2}:$ Rhizobium, $\mathrm{T}_{3}: \mathrm{AM}+$ Rhizobium, $\mathrm{T}_{4}:$ Sclerotium rolfsii, $\mathrm{T}_{5}$ : Sclerotium rolfsii $+\mathrm{AM}, \mathrm{T}_{6}:$ Sclerotium rolfsii + Rhizobium, $\mathrm{T}_{7}:$ Sclerotium rolfsii $+\mathrm{AM}+$ Rhizobium and $\mathrm{T}_{8}$ : Control. Dual inoculation (AM + Rhizobium) increased 20-25\% germination, 50-100\% seed yield and 36-98\% stover yield compared to control. Dual inoculation reduced $44-48 \%$ foot and root rot disease compared to control. On the contrary, Sclerotium rolfsii + Rhizobium, Sclerotium rolfsii $+\mathrm{AM}$, and Sclerotium rolfsii $+\mathrm{AM}+$ Rhizobium reduced $12-17 \%, 16-20 \%$ and $28-31 \%$ foot and root rot disease, respectively compared to only Sclerotium rolfsii trearment. Therefore, arbuscular mycorrhizal fungal species and its combination with rhizobial inoculum were significant both in the formation and effectiveness of AM symbiosis and the reduction of foot and root rot incidence in grasspea plants. Use of these bio-control agents could be promoted as an active component of bio-intensive Integrated Disease Management Program (IDMP) under organic mode.
\end{abstract}

Key words: Foot and root rot, Grasspea (Lathyrus sativus), Rhizobium and Arbuscular mycorrhiza

\section{Introduction}

Sclerotium rolfsii are soil-borne pathogens causing root and foot rot of many crops that commonly occur in the tropical and subtropical regions of the world. Foot rot (caused by Fusarium oxysporum and Sclerotium rolfsii) is considered as an important and destructive disease of pulses in almost all legume-growing countries of the world. It causes seedling death at early stage resulting very poor plant stand which ultimately produces very low yield. Though this disease can be controlled by using chemical pesticide but it causes environmental pollution, health hazards and also is not economical. Hence, biological control agents like arbuscular mycorrhizal fungi and Rhizobium can be used for green, safe and sustainable agriculture. Arbuscular mycorrhizal fungi (AMF) that form symbiotic relationships with the roots of most terrestrial plants are known to improve the nutritional status of their host and to protect plants against several soil-borne plant pathogens ${ }^{1-2}$. The major effect of mycorrhizal fungi in undisturbed ecosystems is to improve the growth of mycorrhizal plants compared to non-mycorrhizal plants ${ }^{3}$. It covers the root of plants so it makes protective physical barrier against diseases also ${ }^{4-5}$. Induce local and systemic resistance against pathogens using a variety of mechanisms including increased mineral nutrition, and the expression of plant genes related to resistance or direct antifungal effects ${ }^{6}$. AMF are currently studied as biological control agents against soil-borne diseases ${ }^{7}$. In this way the use of AMF as inoculants to benefit plant growth and health could contribute to a reduction of the inputs of pesticides and other environmentally harmful agrochemical products currently required for optimal plant growth and health ${ }^{8}$.

There are many disease management methods such as crop rotation, use of resistant varieties and chemical pesticides. However, frequent and indiscriminate use of these pesticides affects the physical, chemical and biological property of the soil. It also affects the non-target organisms and has developed

*Corresponding author:

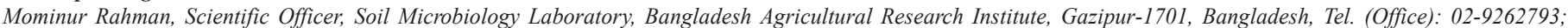
Mobile: 01723098910; Fax number: 88-02-9261415; E-mail: mominurssd13@bari.gov.bd, mominurbau@gmail.com 
resistance among the pathogen against these chemicals ${ }^{9}$. Biocontrol potential of AM fungi against various phytopathogens is well documented ${ }^{10-11}$. Arbuscular Mycorrhizal Fungi (AMF) are the major component of the rhizosphere of most of the plants and play a very important role as biocontrol agent and help in decreasing plant disease incidence ${ }^{12}$. Rhizobium biofertilizer is a significant technology for improving crop productivity and soil fertility because we can use it as a replacement of nitrogenous fertilizer that is not only economically feasible but also environmentally sustainable. It improved nodulation and as well as nitrogen fixation even under adverse soil conditions.

Lathyrus sativus L., commonly known as grasspea, is an annual plant widely grown as a pulse crop and its dried seeds are harvested and consumed as a human food since ancient times ${ }^{13}$. It belongs to the family Fabaceae. In Bangladesh, during 20152016 about 113,528 hectare of land is under grasspea cultivation and the total production is about 122,408 metric tons ${ }^{14}$. At the present time, grasspea cover highest land area in terms of production among other pulses and it is also interesting that it contains highest amount of protein than other pulses that partially fulfill the protein requirement of poor livelihood in our Bangladeshi people. Keeping in mind recent world demand for sustainable agricultural development or green agriculture, biocontrol or renewable natural resources must be emphasized. The present study hypothesized that the combined use of AMF and Rhizobium can improve plant growth and provides protection against the pathogen Sclerotium rolfsii within the context of a sustainable soil-plant system. Therefore, the present investigation was undertaken to investigate the potential of AMF alone and in combination with bio inoculants i.e. Rhizobium to find out the best combination on plant growth, and their biocontrol against grasspea foot and root rot caused by Sclerotium rolfsii.

\section{Materials and Methods}

\section{Seed collection and Soil preparation}

The experiment was carried out during rabi season from December, 2014 to April, 2015 and December, 2015 to April, 2016 in the net house of Soil Science Division, BARI, Joydebpur, Gazipur (230 59'378' N latitude, 90 24'886' E longitude and $8.4 \mathrm{~m}$ elevation). Seeds of grasspea (BARI Khesari-1) were collected from Pulse Research Centre, BARI, Gazipur. The silted (sandy clay loam) soils were collected from the bank of Turag river at Kodda, Gazipur mixed with cowdung at 5:1 ratio and was used as the potting media. Each pot $(25 \mathrm{~cm}$ in diameter and $21 \mathrm{~cm}$ in height) was filled with approximately 6-kg soil leaving upper 3 inches of pot vacant to facilitate watering. The $\mathrm{pH}$ of cowdung was 6.7 and the nutrient contents were: organic matter $14.1 \%$, N $0.8 \%$, P $1.26 \%$, K $0.88 \%$, Ca $1.55 \%, \mathrm{Mg} 0.82 \%$, S
$0.62 \%$, Fe $0.25 \%$ and $\mathrm{Mn} 0.112 \%$. The physical and chemical properties of the soil are presented in Table 1. The soil contained 12 AM $\left(100^{-1} \mathrm{~g}\right.$ soil) spores of indigenous mixed AM fungal species and the experiment was conducted under sterilized soil condition.

\section{Soil analysis}

Soil $\mathrm{pH}$ was measured by a combined glass calomel electrode ${ }^{15}$. Organic carbon was determined by Wet Oxidation Method ${ }^{16}$. Total $\mathrm{N}$ was determined by modified Kjeldahl method ${ }^{17}$. Calcium, $\mathrm{K}$ and $\mathrm{Mg}$ were determined by $\mathrm{NH}_{4} \mathrm{OAc}$ extraction method ${ }^{18}$. Copper, Fe, Mn and $\mathrm{Zn}$ were determined by DTPA extraction followed by AAS reading. Boron was determined by $\mathrm{CaCl}_{2}$ extraction method. Phosphorus was determined by Modified Olsen method (Neutral + Calcareous soils) according to Olsen et al. ${ }^{19}$. Sulphur was determined by $\mathrm{CaH}_{4}\left(\mathrm{PO}_{4}\right)_{2} \cdot \mathrm{H}_{2} \mathrm{O}$ extraction followed by turbidimetric turbidity method with $\mathrm{BaCl}_{2}$.

\section{Fertilizer application}

Chemical fertilizers@6.3 mg P: 9.5 mg K: 1.002 mg S kg-1 soils were applied ${ }^{20}$. Phosphatic fertilizer (TSP), Potassic fertilizer (MoP) and Sulphatic fertilizer (Gypsum) were used as a source of $\mathrm{P}, \mathrm{K}$ and $\mathrm{S}$, respectively. All fertilizers were applied as basal during final land preparation. Peat based rhizobial inoculum (BARI RLs-10) was used in this experiment @ $50 \mathrm{~g}$ $\mathrm{kg}^{-1}$ seed.

\section{Collection of the pathogen Sclerotium rolfsii and Rhizobium inoculum}

Pathogen Sclerotium rolfsii were collected from Plant Pathology Division, BARI, Gazipur which was grown on non seed barley. Non seed barley collected from Plant Breeding Division, BARI, Gazipur. Pathogen Sclerotium rolfsii along with non seed barley $50 \mathrm{~g}$ was used per Sclerotium treatment pot. After disease development, pathogen sclerotia mixed with soil. Rhizobium strain BARI RLs-10 were collected from Soil Microbiology Laboratory, BARI, Gazipur and mixed properly with the seed before sowing when necessary.

\section{Preparation of mycorrhizal inoculum}

The arbuscular mycorrhizal inoculum was prepared from the roots and rhizosphere soils of sorghum. Mycorrhizal species was originally isolated from different AEZ region, using the wet sieving and decanting method. The spores were left to multiply for 6 months on sorghum plants using unsterilized soil, collected from the same site, in the net house of Soil Science Division, BARI. Plants were irrigated with tap water as needed. A mixture of infected sorghum root and soil which contained spores was used as mycorrhizal inoculum. The soil based AM fungal

Table 1. Initial fertility status of the soil samples

\begin{tabular}{|c|c|c|c|c|c|c|c|c|c|c|c|c|c|c|}
\hline \multirow[t]{2}{*}{ Soil Properties } & Texture & $\mathrm{pH}$ & $\mathrm{OM}(\%)$ & $\mathrm{Ca}$ & $\mathrm{Mg}$ & \multirow[t]{2}{*}{$\mathrm{K}$} & \multirow{2}{*}{$\begin{array}{c}\text { Total } \\
\text { N (\%) } \\
\end{array}$} & $\mathrm{P}$ & \multirow[t]{2}{*}{$\mathrm{S}$} & \multirow[t]{2}{*}{ B } & \multirow{2}{*}{$\begin{array}{c}\mathrm{Cu} \\
\mu \mathrm{g} \mathrm{g}^{-1}\end{array}$} & \multirow[t]{2}{*}{$\mathrm{Fe}$} & \multirow[t]{2}{*}{$\mathrm{Mn}$} & \multirow[t]{2}{*}{$\mathrm{Zn}$} \\
\hline & & & \multicolumn{3}{|c|}{ meq $100 \mathrm{~g}^{-1}$} & & & & & & & & & \\
\hline Result & $\begin{array}{c}\text { Sandy } \\
\text { clay loam }\end{array}$ & 7.6 & 0.32 & 6.6 & 2.3 & 0.09 & 0.017 & 12 & 25 & 0.10 & 1.0 & 14 & 1.3 & 0.85 \\
\hline Critical level & - & - & - & 2.0 & 0.5 & 0.12 & - & 10 & 10 & 0.20 & 0.2 & 4.0 & 1.0 & 0.60 \\
\hline
\end{tabular}


inoculum containing approximate 252 spores and infected sorghum root fragments with a minimum infection level was inoculated to each mycorrhizal pot. Figure 1 represents different mycorrhizal spore identified in the Soil Microbiology Laboratory, Soil Science Division, BARI and used for the experiment. The mycorrhizal inoculum were first placed in each pot at $3-5 \mathrm{~cm}$ depth and was covered with a thin soil layer of $1 \mathrm{~cm}$ immediately prior to the seed sowing of grasspea to facilitate fungal colonization of plant roots.

\section{Identification of AM fungal spore}

For the identification of AM fungal spore, single spore or sporocarps were easily picked up from the filter paper with the help of syringe or fine point camel brush and mounted on a glass slide with a drop of polyvinyl lactophenol (PVL) and a cover slip was placed. Subsequently, recovered spores were identified with the help of manual and different taxonomic keys proposed by different workers. Spore morphology, size, shape and peridium of spore, sporocarps colour, wall ornamentation, subtending hyphae and mode of attachment are considered for identification of spore or sporocarps.

\section{Design of experiment and treatments}

The experiment was designed in RCBD with 8 treatments and 4 replications. Fifteen seeds were sown in each pot at $1 \mathrm{~cm}$ soil depth. The 8 treatments were: $\mathrm{T}_{1}$ : Arbuscular mycorrhizal fungi (AMF), $\mathrm{T}_{2}$ :Rhizobium (R), $\mathrm{T}_{3}$ : AMF + Rhizobium, $\mathrm{T}_{4}$ : Sclerotium rolfsii, $\mathrm{T}_{5}$ : Sclerotium rolfsii + AMF, $\mathrm{T}_{6}$ : Sclerotium rolfsii + Rhizobium, $\mathrm{T}_{7}$ : Sclerotium rolfsii $+\mathrm{AMF}+$ Rhizobium and $\mathrm{T}_{8}$ : Control.

\section{Determination of germination percentage}

The germination test was carried out according to ISTA rules ${ }^{21}$. For each treatment, 100 seeds were put into Petri dishes. The Petri dishes were put on a laboratory table at room temperature $\left(25 \pm 2^{\circ} \mathrm{C}\right)$. After 8 days, normal, abnormal and diseased seeds
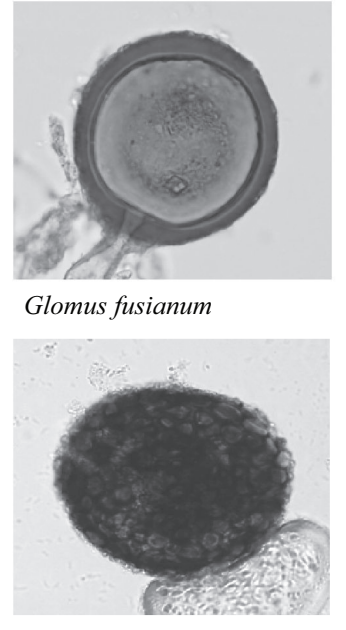

Acaulospora foveata

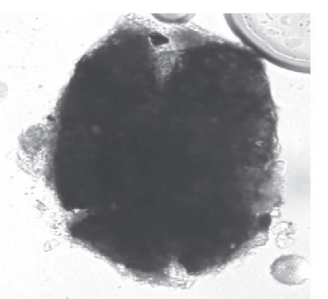

Gigaspora rosea

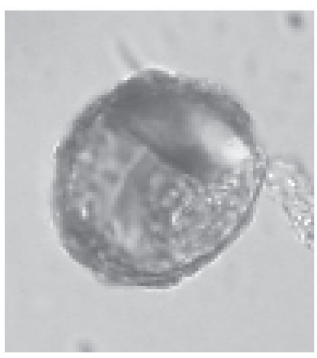

Not identified

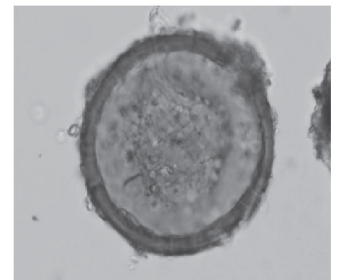

Glomus macrocarpum

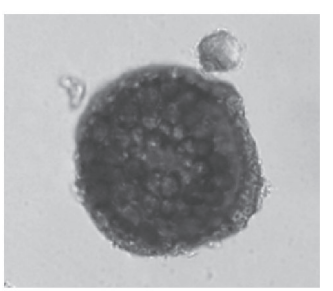

Acaulospora denticulate

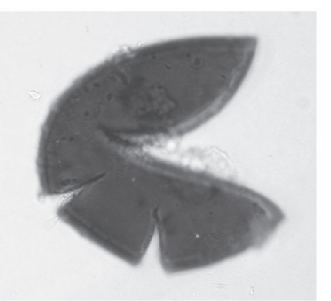

Glomus spp.

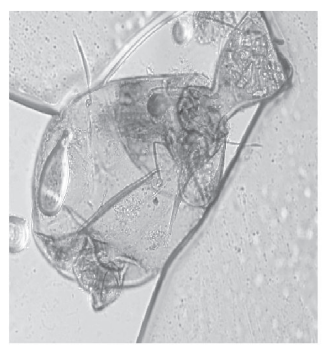

Not identified

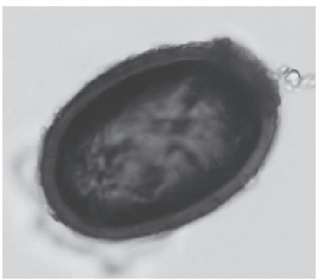

Glomus warcuppi

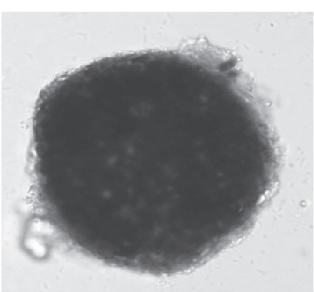

Gigaspora albida

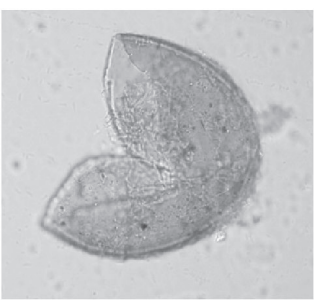

Glomus spp.

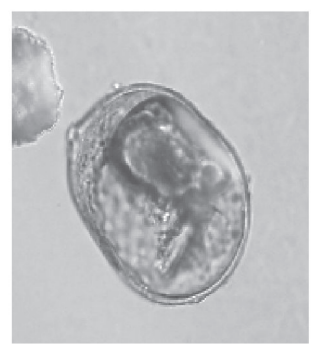

Not identified

Figure 1. Different mycorrhizal spore identified in the Soil Microbiology Laboratory, Soil Science Division, BARI and used for the experiment 
were counted. Germination of grasspea seed in the laboratory table was 95\%. Fifteen seeds were sown in each pot. After 23 days germinated seeds were observed and counted. Germination percentage was calculated by the following formula:

Germination $(\%)=\frac{\text { Number of germinated seeds in each pot }}{\text { Total number of seeds sown in each pot }} \times 100$

Determination of pre and post-emergence foot and root rot (\%)

Pre-emergence foot and root rot was calculated at 11 days after sowing (DAS) and post-emergence foot and root rot was calculated at 11, 15, 19 and 23 DAS by the following formula:

$P_{1}(\%)=\frac{N_{1}}{G_{1}} \times 100$

$P_{2}(\%)=\frac{\mathrm{N}_{2}}{\mathrm{G}_{2}} \times 100$

Where,

$\mathrm{P}_{1}=$ Pre -emergence foot and root rot

$\mathrm{P}_{2}=$ Post -emergence foot and root rot

$\mathrm{N}_{1}=$ Number of non-germinated seeds in each pot at $11 \mathrm{DAS}$

$\mathrm{G}_{1}=$ Total number of seeds sown in each pot
$\mathrm{N}_{2}=$ Number of abnormal or disease infected or dead seedlings in each pot at $23 \mathrm{DAS}$

$\mathrm{G}_{2}=$ Total number of seedlings present in each pot at 11 DAS

Plant harvest

Grasspea were harvested after 132 days after sowing. Different growth parameters like root length and shoot length, root length + shoot length, plant dry weight, pods plant ${ }^{-1}$, seed pod ${ }^{-1}$, total seed weight plant ${ }^{-1}, 1000$-seed weight, seed yield pot $^{-1}$ and stover yield pot $^{-1}$ were measured.

\section{Statistical analysis}

Data were statistically analyzed using Analysis of Variance (ANOVA) following Statistix 10 package.

\section{Results and Discussion}

Germination \% and growth parameters

Effect of inoculation of AMF, Rhizobium and Sclerotium rolfsii on germination $\%$ and growth parameters of grasspea have been presented in Table 2 and Figure 2. Significant differences were found in case of germination $\%$, root length $(\mathrm{cm})$, shoot length $(\mathrm{cm})$, root + shoot length $(\mathrm{cm})$ at harvest and plant dry weight $\left(\mathrm{g} \mathrm{plant}^{-1}\right)$.

The highest germination (80\%) after 23 DAS, root length (7.27 $\mathrm{cm})$, shoot length $(32.58 \mathrm{~cm})$, root + shoot length $(39.85 \mathrm{~cm})$

Table 2. Effect of inoculation of AMF, Rhizobium and Sclerotium rolfsii on germination \% and growth parameters of grasspea

\begin{tabular}{|c|c|c|c|c|c|}
\hline \multirow{2}{*}{$\begin{array}{l}\text { Treatments } \\
\text { after } 23 \text { DAS }\end{array}$} & \multirow[t]{2}{*}{ Germination (\%) } & Root length & Shoot length & Root + shoot length & \multirow{2}{*}{$\begin{array}{l}\text { Plant dry weight } \\
\left.\text { (g plant }^{-1}\right)\end{array}$} \\
\hline & & \multicolumn{3}{|c|}{ (cm at harvest) } & \\
\hline \multicolumn{6}{|l|}{ 2014-2015 } \\
\hline Rhizobium & $73.33 \mathrm{ab}$ & $6.44 \mathrm{ab}$ & $29.67 \mathrm{ab}$ & $36.11 \mathrm{abc}$ & $1.74 \mathrm{abc}$ \\
\hline $\mathrm{AM}+$ Rhizobium & $80.00 \mathrm{a}$ & $7.27 \mathrm{a}$ & $32.58 \mathrm{a}$ & $39.85 \mathrm{a}$ & $1.87 \mathrm{a}$ \\
\hline Sclerotium + Rhi. & $26.67 \mathrm{de}$ & $4.02 \mathrm{c}$ & $30.25 \mathrm{ab}$ & $34.27 \mathrm{abc}$ & $1.62 \mathrm{bc}$ \\
\hline Scle. + AM + Rhi. & $46.67 \mathrm{c}$ & $6.54 \mathrm{ab}$ & $31.25 \mathrm{ab}$ & $37.79 \mathrm{ab}$ & $1.83 \mathrm{ab}$ \\
\hline Control & $66.67 b$ & $6.10 \mathrm{~b}$ & $27.08 \mathrm{~b}$ & $33.18 b c$ & $1.51 \mathrm{~cd}$ \\
\hline $\mathrm{SE}( \pm)$ & 2.61 & 0.32 & 1.57 & 2.08 & 0.18 \\
\hline F test & $* *$ & $* *$ & $* *$ & $* *$ & $* *$ \\
\hline Rhizobium & $65.00 \mathrm{~b}$ & $6.53 a$ & $31.13 \mathrm{ab}$ & $37.66 \mathrm{ab}$ & $1.60 \mathrm{bc}$ \\
\hline $\mathrm{AM}+$ Rhizobium & $80.00 \mathrm{a}$ & $7.49 \mathrm{a}$ & $33.78 \mathrm{a}$ & $41.28 \mathrm{a}$ & $1.95 \mathrm{a}$ \\
\hline Sclerotium & $5.00 \mathrm{f}$ & $4.22 b$ & $16.71 \mathrm{e}$ & $20.93 d$ & $1.14 \mathrm{~d}$ \\
\hline Sclerotium + AM & $31.67 \mathrm{~d}$ & $5.26 \mathrm{~b}$ & $29.28 \mathrm{bcd}$ & $34.54 \mathrm{bc}$ & $1.54 \mathrm{c}$ \\
\hline Sclerotium + Rhi. & $20.00 \mathrm{e}$ & $7.16 \mathrm{a}$ & $26.38 \mathrm{~d}$ & $33.54 \mathrm{c}$ & $1.38 \mathrm{~cd}$ \\
\hline Scle. + AM + Rhi. & $41.67 \mathrm{c}$ & $7.24 \mathrm{a}$ & $26.94 \mathrm{~cd}$ & $34.18 b c$ & $1.83 \mathrm{ab}$ \\
\hline Control & $65.00 \mathrm{~b}$ & $6.85 a$ & $30.79 \mathrm{abc}$ & $37.64 \mathrm{ab}$ & $1.46 \mathrm{c}$ \\
\hline $\mathrm{SE}( \pm)$ & 2.99 & 0.37 & 1.34 & 1.38 & 0.08 \\
\hline F test & $* *$ & $* *$ & $* *$ & $* *$ & $* *$ \\
\hline CV (\%) & 11.56 & 11.56 & 9.46 & 7.92 & 10.60 \\
\hline
\end{tabular}

AM: Arbuscular Mycorrhiza, Rhi.: Rhizobium; Scle.: Sclerotium. The values represent means of 04 replicates. Different letters within each column indicate significant differences between treatments. Test Statistix 10. **Significant Pd"0.01 

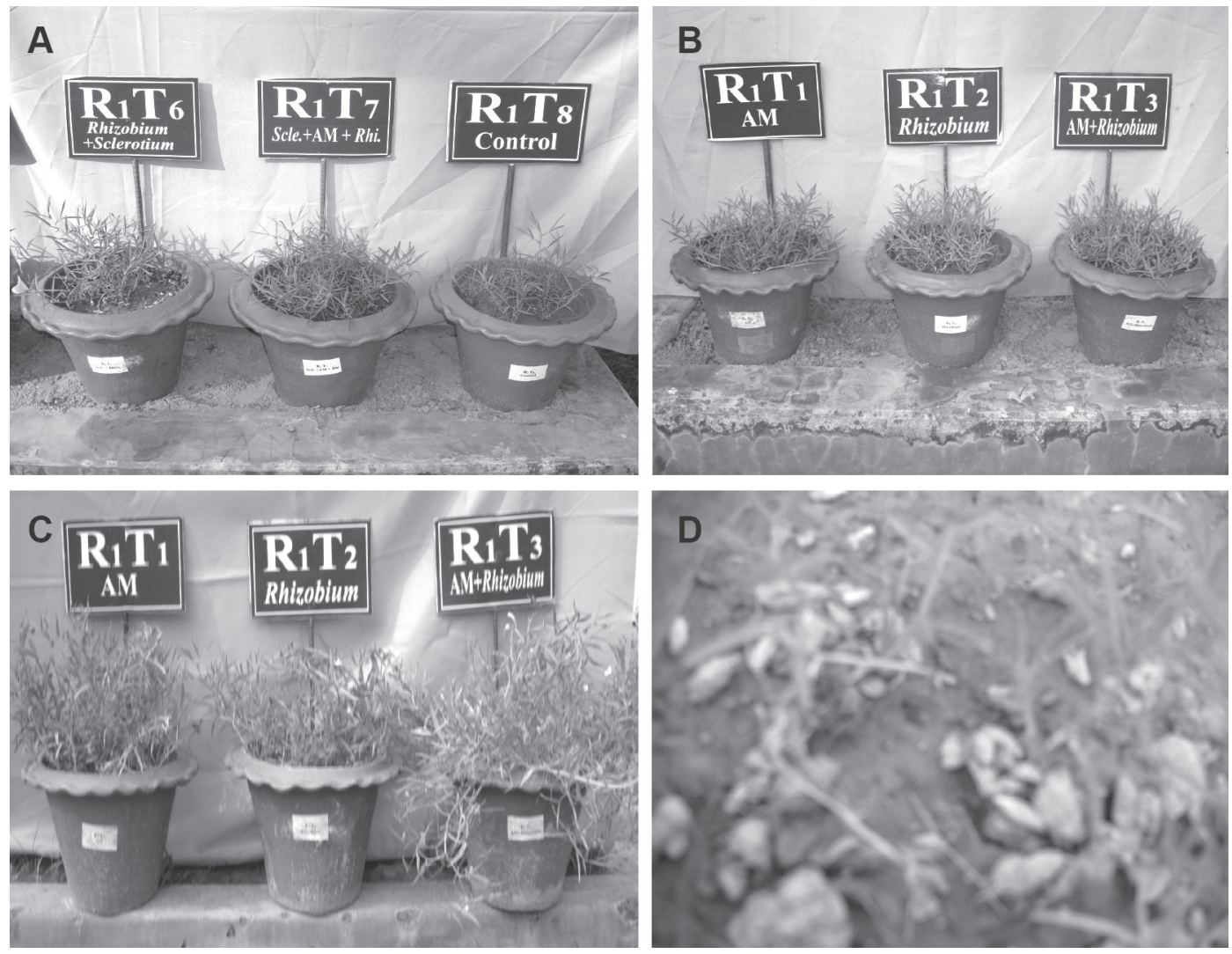

Figure 2. Effect of inoculation of AMF and Rhizobium on grasspea (A and B: Early growth stage, C: Flowering stage, D: Sclerotium rolfsii affected young plants)

and plant dry weight $\left(1.87 \mathrm{~g} \mathrm{plant}^{-1}\right)$ in 2014-2015 and germination $(80 \%)$ after 23 DAS, root length $(7.49 \mathrm{~cm})$, shoot length $(33.78$ $\mathrm{cm})$, root + shoot length $(41.28 \mathrm{~cm})$ and plant dry weight $(1.95 \mathrm{~g}$ plant $^{-1}$ ) in 2015-2016 were observed in AM + Rhizobium treatment (Table 2). The lowest germination (21.67\%) after 23 DAS, root length $(2.57 \mathrm{~cm})$, shoot length $(21.83 \mathrm{~cm})$, root + shoot length $(24.40 \mathrm{~cm})$ and plant dry weight $\left(1.36 \mathrm{~g} \mathrm{plant}^{-1}\right)$ in $2014-2015$ and germination $(5.0 \%)$ after 23 DAS, root length $(4.22 \mathrm{~cm})$, shoot length $(16.71 \mathrm{~cm})$, root + shoot length $(20.93 \mathrm{~cm})$ and plant dry weight (1.14 g plant $\left.{ }^{-1}\right)$ in 2015-2016 were observed in Sclerotium treatment (Table 2). The highest germination in 2014-2015 was found in 'AM + Rhizobium' treatment which was significantly higher over Sclerotium, 'Sclerotium + AM', 'Sclerotium + Rhizobium', 'Sclerotium + AM + Rhizobium' and control treatments but identical to AM and Rhizobium treatments while the highest germination in 2015-2016 was found in 'AM + Rhizobium' treatment which was significantly higher over rest of the treatments. The highest root length in 2014-2015 was found in 'AM + Rhizobium' treatment which was significantly higher over AM, Sclerotium, 'Sclerotium + AM', 'Sclerotium + Rhizobium' and control treatments but identical to Rhizobium and 'Sclerotium + $\mathrm{AM}+$ Rhizobium' treatments while the highest root length in 20152016 was found in 'AM + Rhizobium' treatment which was significantly higher over Sclerotium and 'Sclerotium + AM' treatments but identical to AM, Rhizobium, 'Sclerotium + Rhizobium', 'Sclerotium + AM + Rhizobium' and control treatments. The highest shoot length in 2014-2015 was found in 'AM + Rhizobium' treatment which was significantly higher over
Sclerotium, 'Sclerotium + AM' and control treatments but identical to AM, Rhizobium, 'Sclerotium + Rhizobium' and 'Sclerotium + $\mathrm{AM}+$ Rhizobium' treatments while the highest shoot length in 2015-2016 was found in 'AM + Rhizobium' treatment which was significantly higher over Sclerotium, 'Sclerotium + AM', 'Sclerotium + Rhizobium' and 'Sclerotium + AM + Rhizobium' treatments but identical to AM, Rhizobium and control treatments. The highest root + shoot length in 2015-2016 was found in "AM+ Rhizobium' treatment which was significantly higher over Sclerotium, 'Sclerotium + AM' and control treatments but identical to AM, Rhizobium, 'Sclerotium + Rhizobium' and 'Sclerotium + $\mathrm{AM}+$ Rhizobium' treatments while the highest root + shoot length in 2015-2016 was found in 'AM + Rhizobium' treatment which was significantly higher over Sclerotium, 'Sclerotium + AM', 'Sclerotium + Rhizobium' and 'Sclerotium + AM + Rhizobium' treatments but identical to AM, Rhizobium and control treatments. The highest plant dry weight in 2014-2015 was found in 'AM + Rhizobium' treatment which was significantly higher over 'Sclerotium + Rhizobium' and control treatments but identical to AM, Rhizobium, 'Sclerotium + AM' and 'Sclerotium + AM + Rhizobium' treatments while the highest plant dry weight in 20152016 was found in 'AM + Rhizobium' treatment which was identical to 'Sclerotium + AM + Rhizobium' treatment but significantly higher over rest of the treatments.

Mycorrhizal treatments significantly increased germination (\%) because AMF entangle soil particles within the hyphae, tapping carbon resourses, reduce damage caused by pathogen, influence soil microbial activity, increased mobilization and transfer of nutrients 
and increased availability of added or fixed phosphorus. Researches in the past few decades on various aspects of root symbionts have shown that dual interaction of AM fungi and Rhizobium has improved the growth, nodulation and yield ${ }^{22-23}$. Increased nitrogen fixation in chickpea due to dual inoculation with G. fasciculatum and Rhizobium was reported by Subba Rao et al. ${ }^{24}$.

\section{Yield attributes}

Effect of inoculation of AMF, Rhizobium and Sclerotium rolfsii on yield and yield contributing characters of grasspea have been presented in Figures 3, 4 and Table 3. Significant differences

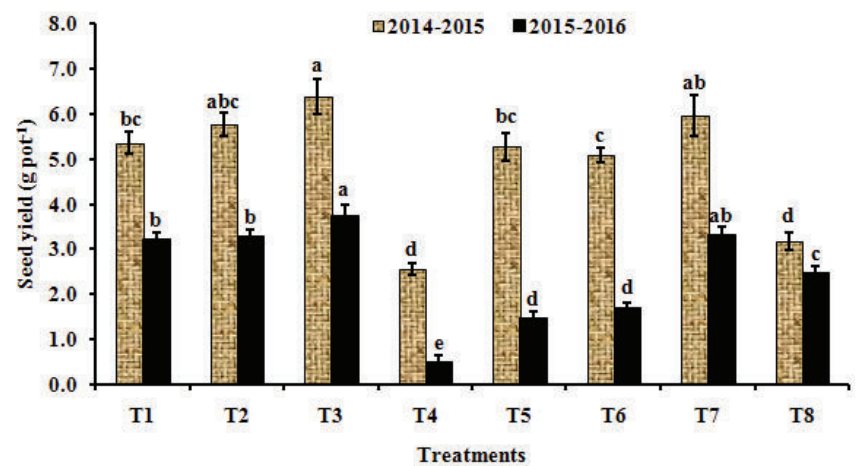

Figure 3. Effect of inoculation of AMF and Rhizobium on seed yield of grasspea. $\mathrm{T}_{1}$ : Arbuscular mycorrhizal fungi (AMF), $\mathrm{T}_{2}$ : Rhizobium (R), $\mathrm{T}_{3}$ : AMF + Rhizobium, $\mathrm{T}_{4}$ : Sclerotium rolfsii, $\mathrm{T}_{5}$ : Sclerotium rolfsii + AMF, $\mathrm{T}_{6}:$ Sclerotium rolfsii + Rhizobium, $\mathrm{T}_{7}$ : Sclerotium rolfsii $+\mathrm{AMF}+$ Rhizobium and $\mathrm{T}_{8}$ : Control. were found in case of pods plant ${ }^{-1}$, seeds pod ${ }^{-1}$, total seed weight $\left(\mathrm{g}\right.$ plant $\left.\mathrm{t}^{-1}\right), 1000$-seed weight $(\mathrm{g})$, seed yield $\left(\mathrm{g} \mathrm{pot}^{-1}\right)$ and stover yield $\left(\mathrm{g}\right.$ pot $\left.^{-1}\right)$.

The highest number of pods (7.33 plant $\left.^{-1}\right)$, number of seeds $(3.35$ pod $\left.^{-1}\right)$, total seed weight $\left(1.02 \mathrm{~g} \mathrm{plant}^{-1}\right), 1000$-seed weight $(72.25$ $\mathrm{g})$, seed yield $\left(6.39 \mathrm{~g} \mathrm{pot}^{-1}\right)$ and stover yield $\left(7.28 \mathrm{~g} \mathrm{pot}^{-1}\right)$ in 2014-2015 and number of pods (6.50 plant $\left.^{-1}\right)$, number of seeds $\left(3.20\right.$ pod $\left.^{-1}\right)$, total seed weight $\left(0.74 \mathrm{~g} \mathrm{plant}^{-1}\right), 1000$-seed weight $(51.25 \mathrm{~g})$, seed yield (3.73 $\left.\mathrm{g} \mathrm{pot}^{-1}\right)$ and stover yield (4.93 $\mathrm{g} \mathrm{pot}^{-}$ 1 ) in 2015-2016 were observed in AM + Rhizobium treatment (Figures 3, 4 and Table 3). The lowest number of pods (4.13

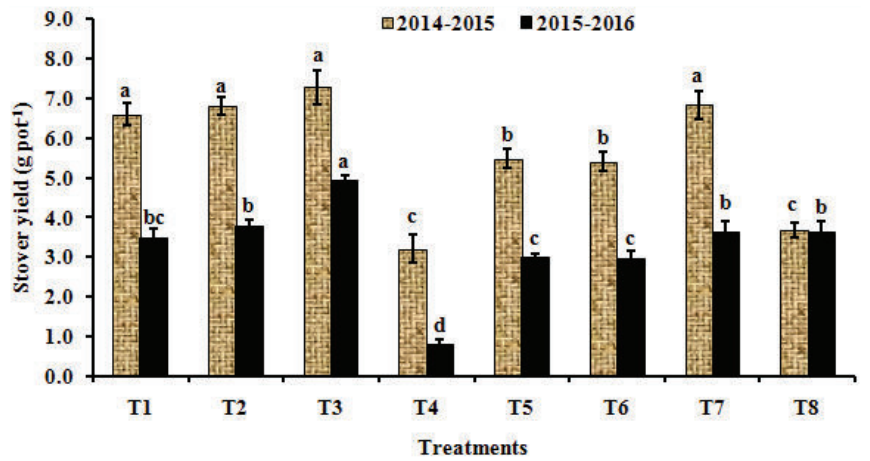

Figure 4. Effect of inoculation of AMF and Rhizobium on stover yield of grasspea. $\mathrm{T}_{1}$ : Arbuscular mycorrhizal fungi (AMF), $\mathrm{T}_{2}$ : Rhizobium (R), $\mathrm{T}_{3}$ : AMF + Rhizobium, $\mathrm{T}_{4}$ : Sclerotium rolfsii, $\mathrm{T}_{5}:$ Sclerotium rolfsii + AMF, $\mathrm{T}_{6}:$ Sclerotium rolfsii + Rhizobium, $\mathrm{T}_{7}$ : Sclerotium rolfsii $+\mathrm{AMF}+$ Rhizobium and $\mathrm{T}_{8}$ : Control.

Table 3. Effect of inoculation of AMF, Rhizobium and Sclerotium rolfsii on yield contributing characters of grasspea

\begin{tabular}{|c|c|c|c|c|}
\hline Treatments & Number of pods(plant $\left.{ }^{-1}\right)$ & Number of seeds $\left(\mathrm{pod}^{-1}\right)$ & Total seed weight $\left(\right.$ g plant $\left.^{-1}\right)$ & 1000-seed weight $(\mathrm{g})$ \\
\hline \multicolumn{5}{|l|}{ 2014-2015 } \\
\hline AM & $6.42 \mathrm{ab}$ & 3.15 & $0.78 b$ & $68.00 \mathrm{ab}$ \\
\hline $\mathrm{AM}+$ Rhizobium & $7.33 \mathrm{a}$ & 3.35 & $1.02 \mathrm{a}$ & $72.25 \mathrm{a}$ \\
\hline Sclerotium & $4.13 \mathrm{e}$ & 2.90 & $0.62 \mathrm{c}$ & $58.50 \mathrm{bc}$ \\
\hline Sclerotium + AM & $5.33 \mathrm{~cd}$ & 3.10 & $0.75 b$ & $59.75 b c$ \\
\hline Control & $4.90 \mathrm{de}$ & 3.10 & $0.67 \mathrm{bc}$ & $51.50 \mathrm{c}$ \\
\hline $\mathrm{SE}( \pm)$ & 0.36 & 0.17 & 0.04 & 3.50 \\
\hline F test & $* *$ & NS & $* *$ & $*$ \\
\hline CV $(\%)$ & 12.81 & 10.56 & 10.67 & 11.12 \\
\hline \multicolumn{5}{|l|}{$2015-2016$} \\
\hline Sclerotium + AM & $5.11 \mathrm{c}$ & $2.60 \mathrm{bc}$ & $0.53 b$ & $41.25 \mathrm{bcd}$ \\
\hline Sclerotium + Rhi. & $4.58 \mathrm{~cd}$ & $2.90 \mathrm{ab}$ & $0.49 b$ & $41.88 \mathrm{bcd}$ \\
\hline Scle. $+\mathrm{AM}+$ Rhi. & $5.83 \mathrm{ab}$ & $3.15 \mathrm{a}$ & $0.70 \mathrm{a}$ & $47.38 \mathrm{ab}$ \\
\hline Control & $5.17 \mathrm{bc}$ & $2.85 \mathrm{ab}$ & $0.52 b$ & $40.88 \mathrm{~cd}$ \\
\hline $\mathrm{SE}( \pm)$ & 0.25 & 0.14 & 0.04 & 2.17 \\
\hline F test & $* *$ & $* *$ & $* *$ & $*$ \\
\hline CV (\%) & 9.43 & 10.19 & 12.12 & 9.99 \\
\hline
\end{tabular}

AM: Arbuscular Mycorrhiza, Rhi.: Rhizobium; Scle.: Sclerotium. The values represent means of 04 replicates. Different letters within each column indicate significant differences between treatments. Test Statistix 10. **Significant Pd"0.01, *significant Pd"0.05, NS non significant. 
plant $\left.{ }^{-1}\right)$, number of seeds $\left(2.90\right.$ pod $\left.^{-1}\right)$, total seed weight $(0.62 \mathrm{~g}$ plant $\left.{ }^{-1}\right), 1000$-seed weight $(58.50 \mathrm{~g})$, seed yield $\left(2.54 \mathrm{~g} \mathrm{pot}^{-1}\right)$ and stover yield (3.20 $\left.\mathrm{g} \mathrm{pot}^{-1}\right)$ in 2014-2015 and number of pods (4.25 plant $\left.{ }^{-1}\right)$, number of seeds $\left(2.25\right.$ pod $\left.^{-1}\right)$, total seed weight $\left(0.49 \mathrm{~g} \mathrm{plant}^{-1}\right), 1000$-seed weight $(38.50 \mathrm{~g})$, seed yield $(0.50 \mathrm{~g}$ pot $\left.^{-1}\right)$ and stover yield $\left(0.79 \mathrm{~g} \mathrm{pot}^{-1}\right)$ in 2015-2016 were observed in Sclerotium treatment (Figures 3, 4 and Table 3). The highest pods plant ${ }^{-1}$ in 2014-2015 was found in 'AM + Rhizobium' treatment which was identical to AM treatment but significantly higher over rest of the treatments while the highest pods plant ${ }^{-1}$ in 2015-2016 was found in 'AM + Rhizobium' treatment which was identical to 'Sclerotium + AM + Rhizobium' treatment but significantly higher over rest of the treatments. The highest seeds pod $^{-1}$ in 2014-2015 was found in 'AM + Rhizobium' treatment which were non-significant among the treatments while the highest seeds pod ${ }^{-1}$ in 2015-2016 was found in 'AM + Rhizobium' treatment which was significantly higher over Sclerotium and 'Sclerotium + AM' treatments but identical to AM, Rhizobium, 'Sclerotium + Rhizobium', 'Sclerotium + AM + Rhizobium' and control treatments. The highest total seed weight $\left(\mathrm{g} \mathrm{plant}^{-1}\right)$ in 2014-2015 was found in 'AM + Rhizobium' treatment which was identical to 'Sclerotium + AM + Rhizobium' treatment but significantly higher over rest of the treatments while the highest total seed weight $\left(\mathrm{g} \mathrm{plant}^{-1}\right)$ in 2015-2016 was found in 'AM + Rhizobium' treatment which was identical to AM, Rhizobium, 'Sclerotium $+\mathrm{AM}+$ Rhizobium' treatment but significantly higher over rest of the treatments. The highest 1000 -seed weight (g) in 2014-2015 was found in 'AM + Rhizobium' treatment which was significantly higher over Sclerotium, 'Sclerotium + AM' and control treatments but identical to AM, Rhizobium, 'Sclerotium + Rhizobium' and 'Sclerotium + AM + Rhizobium' treatments while the highest 1000-seed weight (g) in 2015-2016 was found in 'AM + Rhizobium' treatment which was significantly higher over Rhizobium, Sclerotium, 'Sclerotium + AM', 'Sclerotium + Rhizobium' and control treatments but identical to AM and 'Sclerotium + AM + Rhizobium' treatments. The highest seed yield in 2014-2015 was found in 'AM + Rhizobium' treatment which was significantly higher over AM, Sclerotium, 'Sclerotium + AM', 'Sclerotium + Rhizobium' and control treatments but identical to Rhizobium and 'Sclerotium + AM + Rhizobium' treatments while the highest seed yield in 2015-2016 was found in 'AM + Rhizobium' treatment which was identical to 'Sclerotium $+\mathrm{AM}+$ Rhizobium' but significantly higher over rest of the treatments. The highest stover yield in 2014-2015 was found in 'AM + Rhizobium' treatment which was significantly higher over Sclerotium, 'Sclerotium + AM', 'Sclerotium + Rhizobium' and control treatments but identical to AM, Rhizobium and 'Sclerotium + AM + Rhizobium' treatments while the highest stover yield in 2015-2016 was found in 'AM + Rhizobium' treatment which was significantly higher over all the treatments.

These are more or less similar to the findings of the following researchers. Dual inoculation of AM fungi and Rhizobium had improved the growth, nodulation and yield ${ }^{22-23}$ and also nutrient status $^{23,25}$ in legumes. Increased nitrogen fixation in chickpea due to dual inoculation with G. fasciculatum and Rhizobium was reported by Subba Rao et al. ${ }^{24}$.
Foot and root rot disease infection with Sclerotium rolfsii in grasspea seedlings

Effect of dual inoculation of AMF and Rhizobium on foot and root rot disease infection with Sclerotium rolfsii in grasspea seedlings have been presented in Table 4 and Figure 5. Significant differences were found in case of pre-emergence foot and root rot (\%) and post-emergence foot and root rot (\%).

The highest pre-emergence foot and root rot $(73.33 \%)$, total postemergence foot and root rot (13.33\%) and highest 'pre + post' emergence foot and root rot (83.33\%) in 2014-2015 were observed in Sclerotium, 'Sclerotium $+\mathrm{AM}+$ Rhizobium' and Sclerotium treatment, respectively. In contrast, the highest preemergence foot and root rot $(93.33 \%)$, total post-emergence foot and root rot (5.01\%) and highest 'pre + post' emergence foot and root rot (98.34\%) in 2015-2016 were observed in Sclerotium treatment (Table 4 and Figure 5). The lowest pre-emergence foot and root rot $(21.67 \%)$, total post-emergence foot and root rot $(1.67 \%)$ and lowest 'pre + post' emergence foot and root rot $(23.33 \%)$ in 2014-2015 and the lowest pre-emergence foot and root rot $(25.00 \%)$, total post-emergence foot and root rot $(0.00 \%)$ and lowest 'pre + post' emergence foot and root rot $(25.00 \%)$ in 2015-2016 was observed in 'AM + Rhizobium' treatment (Table 4 and Figure 5). The highest pre-emergence foot and root rot in 2014-2015 was found in Sclerotium treatment which was significantly higher over AM, Rhizobium, Sclerotium, 'Sclerotium + AM', 'Sclerotium + AM + Rhizobium' and control treatments but identical to 'Sclerotium + Rhizobium' treatment while the highest pre-emergence foot and root rot in 2015-2016 was found in Sclerotium treatment which was significantly higher over all the treatments. The highest post-emergence foot and root rot (\%) at 15 DAS in 2014-2015 was found in 'Sclerotium + AM' treatment which was significantly higher over all the treatments while the highest post-emergence foot and root rot (\%) at 15 DAS in 2015-2016 was found in 'Sclerotium + AM' treatment which was significantly higher over all the treatments but identical to 'Sclerotium + Rhizobium' treatment. The highest postemergence foot and root rot (\%) at 19 DAS in 2014-2015 was found in AM, Rhizobium and 'Sclerotium + AM + Rhizobium' treatments which was significantly higher over remaining treatments while the highest post-emergence foot and root rot (\%) at 19 DAS in 2015-2016 was found in Sclerotium treatment which was significantly higher over remaining treatments. The highest post-emergence foot and root rot (\%) at 23 DAS in 20142015 was found in Sclerotium treatment which was significantly higher over all the treatments. The highest 'pre + post' emergence foot and root rot (\%) in 2014-2015 and 2015-2016 was found in Sclerotium treatment which was significantly higher over all the treatments.

Different studies revealed that simultaneous inoculation with AM and Rhizobium leguminosarum increased plant tolerance to a variety of pathogens causing seedling diseases ${ }^{26}$. Arbuscular mycorrhizal colonization may also protect host roots, especially 
Table 4. Effect of dual inoculation of AMF and Rhizobium on foot and root rot disease infection with Sclerotium rolfsii in grasspea seedlings

\begin{tabular}{|c|c|c|c|c|c|c|}
\hline \multirow[t]{2}{*}{ Treatments } & \multirow{2}{*}{$\begin{array}{l}\text { Pre-emergence foot } \\
\text { and root rot }(\%)\end{array}$} & \multicolumn{4}{|c|}{ Post-emergence foot and root rot (\%) } & \multirow[b]{2}{*}{ Total } \\
\hline & & $11 \mathrm{DAS}$ & 15 DAS & 19 DAS & 23 DAS & \\
\hline \multicolumn{7}{|l|}{$2014-2015$} \\
\hline $\mathrm{AM}$ & $26.67 \mathrm{de}$ & 0.00 & $0.00 \mathrm{c}$ & $3.33 \mathrm{a}$ & $1.67 \mathrm{~d}$ & 5.00 \\
\hline Rhizobium & $33.33 d$ & 0.00 & $0.00 \mathrm{c}$ & $3.33 \mathrm{a}$ & $0.00 \mathrm{e}$ & 3.33 \\
\hline $\mathrm{AM}+$ Rhizobium & $21.67 \mathrm{e}$ & 0.00 & $0.00 \mathrm{c}$ & $0.00 \mathrm{c}$ & $1.67 \mathrm{~d}$ & 1.67 \\
\hline Sclerotium & $73.33 \mathrm{a}$ & 0.00 & $0.00 \mathrm{c}$ & $1.67 \mathrm{~b}$ & $8.33 \mathrm{a}$ & 10.00 \\
\hline Sclerotium + AM & $58.33 b$ & 0.00 & $5.00 \mathrm{a}$ & $0.00 \mathrm{c}$ & $6.67 b$ & 11.67 \\
\hline Sclerotium + Rhi. & $68.33 \mathrm{a}$ & 0.00 & $0.00 \mathrm{c}$ & $0.00 \mathrm{c}$ & $5.00 \mathrm{c}$ & 5.00 \\
\hline Scle. $+\mathrm{AM}+$ Rhi. & $46.67 \mathrm{c}$ & 0.00 & $3.33 b$ & $3.33 \mathrm{a}$ & $6.67 \mathrm{~b}$ & 13.33 \\
\hline Control & $41.67 \mathrm{c}$ & 0.00 & $0.00 \mathrm{c}$ & $1.67 \mathrm{~b}$ & $1.67 \mathrm{~d}$ & 3.33 \\
\hline $\mathrm{SE}( \pm)$ & 2.41 & - & 0.14 & 0.15 & 0.32 & - \\
\hline F test & $* *$ & - & $* *$ & $* *$ & $* *$ & - \\
\hline CV (\%) & 10.42 & - & 27.04 & 18.39 & 16.05 & - \\
\hline \multicolumn{7}{|l|}{$2015-2016$} \\
\hline $\mathrm{AM}$ & $33.33 \mathrm{e}$ & 0.00 & $0.00 \mathrm{c}$ & $0.00 \mathrm{c}$ & 0.00 & 0.00 \\
\hline Rhizobium & $43.33 \mathrm{~d}$ & 0.00 & $0.00 \mathrm{c}$ & $0.00 \mathrm{c}$ & 0.00 & 0.00 \\
\hline $\mathrm{AM}+$ Rhizobium & $25.00 \mathrm{f}$ & 0.00 & $0.00 \mathrm{c}$ & $0.00 \mathrm{c}$ & 0.00 & 0.00 \\
\hline Sclerotium & $93.33 \mathrm{a}$ & 0.00 & $1.67 \mathrm{~b}$ & $3.34 \mathrm{a}$ & 0.00 & 5.01 \\
\hline Sclerotium + AM & $75.00 \mathrm{~b}$ & 0.00 & $3.34 \mathrm{a}$ & $0.00 \mathrm{c}$ & 0.00 & 3.34 \\
\hline Sclerotium + Rhi. & $78.33 b$ & 0.00 & $3.34 \mathrm{a}$ & $0.00 \mathrm{c}$ & 0.00 & 3.34 \\
\hline Scle. $+\mathrm{AM}+$ Rhi. & $56.67 \mathrm{c}$ & 0.00 & $0.00 \mathrm{c}$ & $1.67 \mathrm{~b}$ & 0.00 & 1.67 \\
\hline Control & $45.00 \mathrm{~d}$ & 0.00 & $0.00 \mathrm{c}$ & $0.00 \mathrm{c}$ & 0.00 & 0.00 \\
\hline $\operatorname{SE}( \pm)$ & 2.42 & - & 0.11 & 0.10 & - & - \\
\hline F test & $* *$ & - & $* *$ & $* *$ & - & - \\
\hline CV $(\%)$ & 8.59 & - & 21.29 & 32.45 & - & - \\
\hline
\end{tabular}

AM: Arbuscular Mycorrhiza, Rhi.: Rhizobium; Scle.: Sclerotium. The values represent means of 04 replicates. Different letters within each column indicate significant differences between treatments. Test Statistix 10. **Significant Pd”0.01.

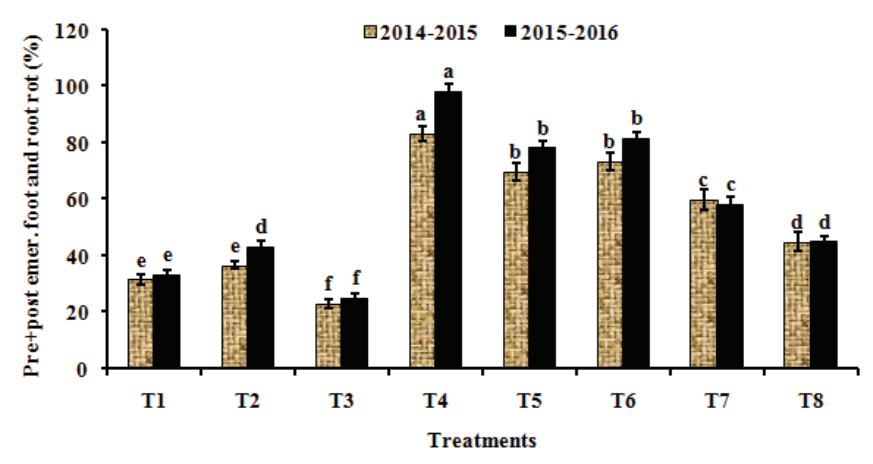

Figure 5. Effect of dual inoculation of AMF and Rhizobium on 'pre+ post' emergence foot and root rot disease \% in grasspea. $\mathrm{T}_{1}$ : Arbuscular mycorrhizal fungi (AMF), $\mathrm{T}_{2}:$ Rhizobium (R), $\mathrm{T}_{3}: \mathrm{AMF}+$ Rhizobium, $\mathrm{T}_{4}:$ Sclerotium rolfsii, $\mathrm{T}_{5}$ : Sclerotium rolfsii + AMF, $\mathrm{T}_{6}:$ Sclerotium rolfsii + Rhizobium, $\mathrm{T}_{7}$ : Sclerotium rolfsii $+\mathrm{AMF}+$ Rhizobium and $\mathrm{T}_{8}$ : Control.

under nutrient limitation ${ }^{27}$. Larsen and Bodker ${ }^{28}$ found that arbuscular mycorrhizal fungi played positive role in the areas of disease suppression. In a recent study, the presence of arbuscular mycorrhiza in pea roots was shown to reduce the disease and the effect on a pathogen was measured by recording the enzymatic activity of the pathogen under influence of the AM fungus ${ }^{29}$.

\section{Conclusions}

Dual inoculation increased $20-25 \%$ germination, $50-100 \%$ seed yield and $36-98 \%$ stover yield compared to control. Dual inoculation reduced $44-48 \%$ foot and root rot disease compared to control. On the other hand, 'Sclerotium rolfsii + Rhizobium', 'Sclerotium rolfsii + AM', and 'Sclerotium rolfsii + AM + Rhizobium' reduced $12-17 \%, 16-20 \%$ and $28-31 \%$ foot and root rot disease, respectively compared to only Sclerotium rolfsii treatment. Therefore, arbuscular mycorrhizal fungal species and its combination with rhizobial inoculum were significant both in the formation and effectiveness of AM symbiosis and the reduction of foot and root rot incidence in grasspea plants. The findings of this study suggest among all treatments, dual combination of AMF plus Rhizobium was most effective in increasing germination (\%), growth parameters, and yield contributing characters. Furthermore, combinations of AMF and 
Rhizobium were able to control foot and root rot disease of grasspea more effectively than either bio control agent applied alone which would be the important basis of sustainable agricultural systems. Interactions between these two microbial agents should be researched deeply to understand the mechanisms involved in belowground and above-ground community via plants. This combination can be further tested under field conditions and can be recommended to the farmers after proper confirmation.

\section{References}

1. Harrison MJ. 1999. Molecular and cellular aspects of the arbuscular mycorrhizal symbiosis. Ann. Rev. Plant Physiol. Plant Mol. Biol. 50: 361-389.

2. Bi HH, Song YY and Zeng RS. 2007. Biochemical and molecular responses of host plants to mycorrhizal infection and their roles in plant defense. Allelopath. J. 29: 15-27.

3. Plenchette C, Fortin JA and Furlan V. 1983. Growth responses of several plant species to mycorrhizae in a soil of moderate $P$ fertility. I. Mycorrhizal dependency under field conditions. Plant Soil. 70: 199-209.

4. McAllister CB, Garcia-Garrido JM, Garcia-Romera I, Godeas A and Ocampo JA. 1997. Interaction between Alternaria alternata or Fusarium equiseti and Glomus mosseae and its effects on plant growth. Plant Soil. 24(3): 301-305.

5. Karagiannidis N, Bletsos F and Stavropoulos N. 2002. Effect of verticillium wilt (Verticilliumdahlia Kleb.) and mycorrhiza (Glomus mosseae) on root colonization, growth and nutrient uptake in tomato and eggplant seedlings. Scientia Horticulturae. 94(1-2): 145-156.

6. Aghighi S, Shahidi Bonjar GH and Saadoun I. 2004. First report of antifungal properties of a new strain of Streptomyces plicatus (strain 101) against four Iranian phytopathologenic isolates of Verticillium dahlia, a new horizon in biocontrol agents. Biotechnol. 3: 90-97.

7. Hooker JE, Jaizme-Vega M and Alkinson D. 1994. Biocontrol of Plant Pathogen Using Arbuscular Mycorrhizal Fungi. In: Impact of Arbuscular Mycorrhizas on Sustainable Agriculture and Natural Ecosystems, Gianinazzi S and Schhepp H (Eds.). Birkhauser Verlag, Basle, Switzerland, pp 191-209.

8. Barea JM, Azc'on-Aguilar C and Azc' on R. 1997. Interactions between mycorrhizal fungi and rhizosphere microorganisms within the context of sustainable soil-plant systems, in Multitrophic Interactions in Terrestrial Systems, Ed. by Gange AC and Brown VK. Blackwell Sci. Cambridge, pp 65-77.

9. Arwry TA and Quandt SA. 2003. Pesticides at work and at home: Exposure of migrant farmworkers. Lancet. 362: 2021-2021.

10. Xavier LJC and Boyetchko SM. 2014. Arbuscular mycorrhizal fungi in plant disease control. In: Arora DK. (ed) Fungal biotechnology in agricultural, food, and environmental applications. Dekker, New York, pp 183-194.

11. St-Arnaud M and Vujanovic V. 2007. Effect of the arbuscular mycorrhizal symbiosis on plant diseases and pests. In: Hamel C and Plenchette C. (eds). Mycorrhizae in crop production: applying knowledge. Haworth, Binghampton NY. USA, pp 67-122.
12. Akthar MS and Siddiqui ZA. 2008. Arbuscular mycorrhizal fungi as potential bioprotectants against plant pathogens. In: Mycorrhizae; Sustainable Agriculture and Forestry, Siddiqui ZA, Akhtar MS and Futai K. (Eds.). Springer Netherlands, Dordrecht, The Netherlands.

13. Tamburino R, Guida V, Pacifico S, Rocco M, Zarelli A, Parente A and Di Maro A. 2012. Nutritional values and radical scavenging capacities of grasspea (Lathyrus sativus L.) seeds in Valle Agricola district, Italy. AJCS. 6(1): $149-156$

14. BBS. 2016. Yearbook of Agricultural Statistics (28 $8^{\text {th }}$ series). Bangladesh Bureau of Statistics. Statistics and Information Division. Ministry of Planning, Government of the People's Republic of Bangladesh. pp 101.

15. Jackson, M.L. 1958. Soil Chemical Analysis. Constable and Co. Ltd., London.

16. Walkey A and Black IA. 1934. An examination of degtiareff method for determining soils organic matter and a proposed modification of the chromic acid titration method. Soil Sci. 37: 29-38.

17. Jackson ML. 1962. Soil Chemical Analysis. Constable and Co. Ltd. London.

18. Black CA. 1965. Methods of Soil Analysis. Part I and II. American Soc. of Argon. Inc. Pub. Madison, Wisconsin, USA.

19. Olsen SR, Cole CV, Watanabe FS and Dean LA. 1954. Estimation of available phosphorus in soils by extraction with sodium bicarbonate. U.S. Dept. Agric. Circ. pp 939.

20. BARC (Bangladesh Agricultural Research Council). 2012. Fertilizer Recommendation Guide. Bangladesh Agricultural Research Council, Farmgate, New Airport Road, Dhaka-1215. pp 103.

21. ISTA (International Seed Testing Association). 1976. International Rules for Seed Testing. Seed Sci. and Tech. 4: 3-49.

22. Gill TS and Singh RS. 2002. Effects of Glomus fasciculatum and Rhizobium inoculation on V.A. mycorrhizal colonization and plant growth of chickpea. Indian Phytopath. 32(2): 162-166.

23. Talaat NB and Abdallah AM. 2008. Response of fababean (Vicia fava L.) to dual inoculation with Rhizobium and VA mycorrhiza under different levels of N and P fertilization. J. Applied Sci. Res. 4(9): 1092-1102.

24. Subba Rao NS, Tilak KVPR and Singh CS. 1985. Synergistic effect of Vesicular-Arbuscular mycorrhiza and Azospirillum brasilense on growth of barley in pots. Soil Biol. Biochem. 19: 119-122.

25. Chakrabarty J, Chatterjee NC and Dutta S. 2007. Interactive effect of VAM and Rhizobium on nutrient uptake and growth of Vigna mungo. J. Mycopath. Res. 45(2): 289-291.

26. Lynd JQ and Ansman TR. 1994. Lichen mycobionts mycorrhizal symbiosis with nitrogen-fixation of showy partridge pea. J. Plant Nutr. 17(2-3): 445-459.

27. Graham JH. 2001. What do root pathogens see in mycorrhizas? New Phytol. 148: 357-359.

28. Larsen J and Bodker L. 2001. Interactions between pea root-inhabiting fungi examined using signature fatty acids. New Phytol. 149: 487-493.

29. Kjøller R and Rosendahl S. 1996. The presence of the arbuscular mycorrhizal fungus Glomus intraradices influences enzymatic activities of the root pathogen Aphanomyces euteiches in pea roots. Mycorrhiza. 6: 487-491. 